\title{
Antibacterial and Pesticidal activity of Marine Sponges Sigmadocia fibulata (Schmidt) and Suberites carnosus (Johnston) collected from West Coast of Mumbai, India
}

\author{
Bhadekar N. S, Zodape G. V"
}

Department of Zoology, S. S. \& L. S. Patkar College of Arts and Science \& V. P. Varde College of Commerce \& Economics, S. V. Road, Goregaon West, Mumbai- 400 062, India

\author{
DOI: $10.36348 /$ simps.2021.v07i01.006 \\ *Corresponding author: Dr. Gautam Vithobaji Zodape
}

| Received: 28.12.2021 | Accepted: 12.01.2021 | Published: 14.01.2021

Abstract

Marine sponges are on focus for their ability to produce compounds with antimicrobial activity. The aim of the current study was to screen extracts derived from marine sponge Sigmadocia fibulata (Schmidt) and Suberites carnosus (Johnston) for their activity against selected bacterial fungal and pestecidal pathogens. The crude extract derived from Sigmadocia fibulata (Schmidt) and Suberites carnosus (Johnston) were found potent against tested E. coli and P. mirabilis bacteria. The crude extract of both the sponges showed pasticidal activities against Periplanata Americana and Sitopbilus oryzae. No activity was noted against fungus when tested with crude extract of Sigmadocia fibulata (Schmidt) and Suberites carnosus (Johnston). Thus confirms that the crude extract of Sigmadocia fibulata (Schmidt) and Suberites carnosus (Johnston) have antibacterial and anti pesticidal property.

Keywords: Bacteria, fungus, Sponge, bioactivity, bacteria, pest, fungus.

Copyright $\odot$ 2021 The Author(s): This is an open-access article distributed under the terms of the Creative Commons Attribution 4.0 International License (CC BY-NC 4.0) which permits unrestricted use, distribution, and reproduction in any medium for non-commercial use provided the original author and source are credited.

\section{INTRODUCTION}

Sponges are simple multicellular sessile animals with no true tissue layers or organs [1]. They populate tropical and subtropical benthic marine habitats but are also found at higher latitudes and even in freshwater lakes and streams [2]. As sessile filter feeders, they pump large volumes of water through a specialized canal system, known as its aquiferous system [1]. Marine sponges are a rich source of structurally novel and biologically active metabolites [3]. Over $60 \%$ of potentially useful bioactive compounds discovered so far from living organisms have been obtained from marine fauna, $70 \%$ of which comes from sponges [4]. There are approximately 15,000 different species of sponges throughout the globe, 150 of which occur in freshwater, but only about 17 present have commercial value for traditional use, including the cosmetic industry. A total of 486 sponge species have been found in Indian waters [5]. The sponge class Demospongiae is known for producing the largest number and diversity of secondary metabolites isolated from marine invertebrates [6]. There is a worldwide interest in marine natural products as one of the few de novo sources of drug discovery [7].

The earth's oceans are the last great frontier in the search for plants and organisms with pharmaceutical value [8]. The world health organization (WHO) approximates that $80 \%$ of the worlds inhabitants depend mainly on traditional medicine for their primary health care [9]. Medicines of natural products origin are collected from variety of sources, including terrestrial plants, terrestrial microorganism, marine animals and terrestrial vertebrates and invertebrates [10]. Natural products and other related synthetic analogues are used to treat $87 \%$ of all categorized human diseases, and the discovery of novel agents is often used to better understand targets and pathways in disease process [11].

Studies on bioactive compounds are being extensively studied in Japan, China \& other western countries, but in the developing countries like India, Marine organisms have been explored for the isolation but have not been explored for its structural elucidation. The Indian sub-continent, having a coastline of above $8014 \mathrm{~km}$, offers potential for pursuing marine biotechnology research for discovering novel biologically active compounds that could be used in a large spectrum of human ailments and harvest bio resources for sustainable development with this context. Indian labs have concentrated on bioactive substances from marine animals such as horseshoe crab, green mussels, sponges and corals for characterization of

Citation: Bhadekar N. S \& Zodape G. V (2021). Antibacterial and Pesticidal activity of Marine Sponges Sigmadocia fibulata (Schmidt) 32 and Suberites carnosus (Johnston) collected from West Coast of Mumbai, India. Saudi J Med Pharm Sci, 7(1): 32-38. 
novel molecules. The Department of Biotechnology (DBT) has been promoting marine biotechnology in India for the last one and half decade. Many $R \& D$ programs sponsored on marine biotechnology are leading towards products and process developments and development of a viable technology for the commercial production systems.

The work carried out by NIO [12] and others consist of bioactivity of the compounds collected from the coast of south and south - east India. A very scanty work has been reported by Venkateshvaran [13]; - CIFE Mumbai, \& no effort has gone into unraveling the details on the bioactive compounds. However, Zodape and Kulkarni [14] have been explored for the isolation of bioactive compounds from intertidal crab Leptodius exaratus of Mumbai coast and have concluded that, the Mumbai coast is under deterioration due to the presence of dinoflagellates and bacteria which are eaten by the marine animals causing the presence of toxic compounds in the body. Therefore by taking an account of these studies we have collected the sponges fromwest coast of Mumbai to explore the antibacterial and Pesticidal activity of Sigmadocia fibulata (Schmidt) and Suberites carnosus (Johnston).

\section{Materials and Methods Collection of Samples}

The sponges Sigmadocia fibulata (Schmidt) and Suberites carnosus (Johnston) were collected during low tides from West Coast of Mumbai. Animals were taken alive to the laboratory in seawater washed under sea water and then with distilled water and sun dried.

\section{Identification of Sponges}

Preliminary identification was done by studying the shape and size of the spicules and by refereeing the relevant literature. The confirmation of identification was done by Dr. P. A. Thomas, Principal Scientist, Central Marine Fisheries Research Institute (CMFRI), Thiruvananthapuram, Kerala.

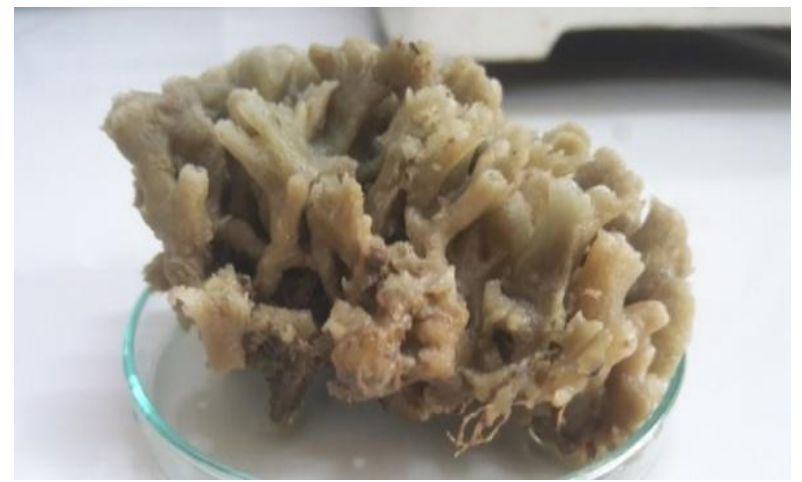

Sigmadocia fibulata (Schmidt, 1862)

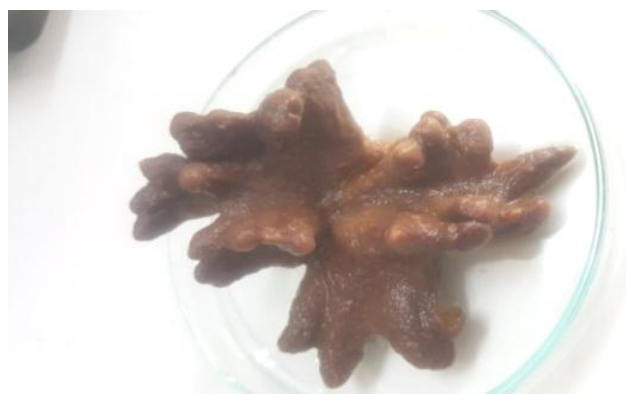

Suberites carnosus (Johnston, 1842)

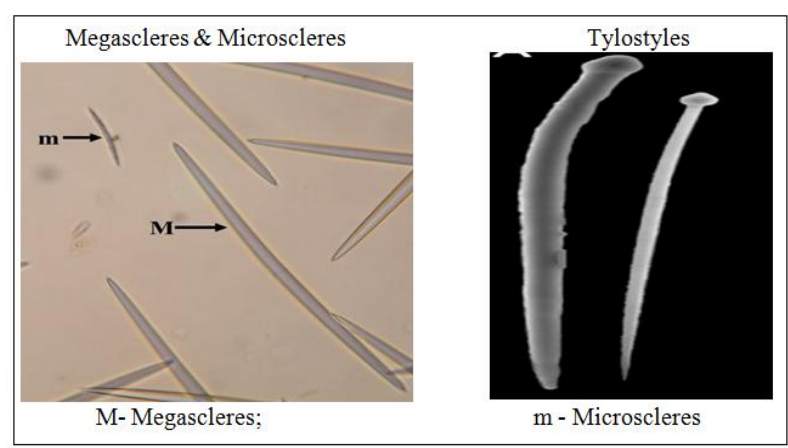

Preparation of Sponge Extracts

Crude extract was obtained following the method of Braekman et al., 1992 [15] with some modifications. To 10 gram of sponge samples, $10 \mathrm{ml}$ of methanol was added and kept standing for $24 \mathrm{hrs}$. Solvent were then removed, by squeezing sponge samples, and filtered through Whatman filter paper No.1. The remaining solvent was evaporated at low pressure using Rotary Vacuum Evaporator at $45^{\circ} \mathrm{C}$. The resultant compound was subjected to Millipore filter system and finally dried in a vacuum desiccator and stored at $4^{\circ} \mathrm{C}$ in a refrigerator till further use.

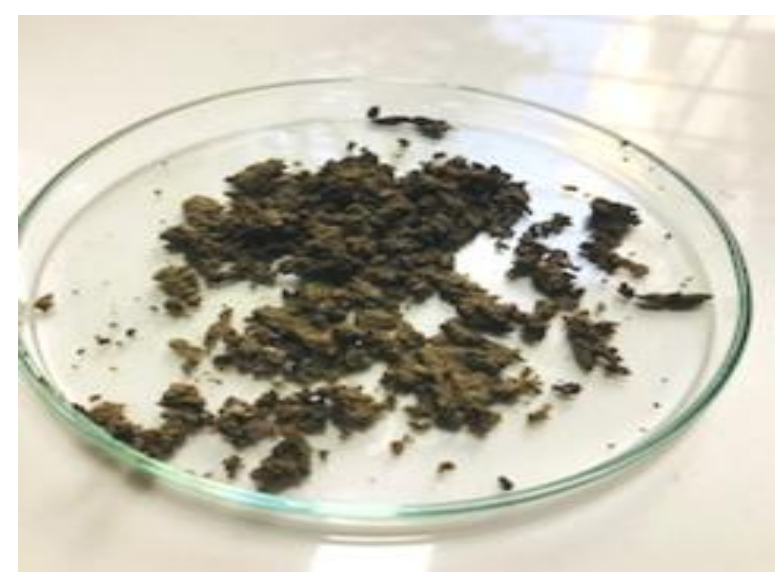

Sigmadocia fibulata (Schmidt, 1862) 
Bhadekar N. S \& Zodape G. V., Saudi J Med Pharm Sci, Jan, 2021; 7(1): 32-38

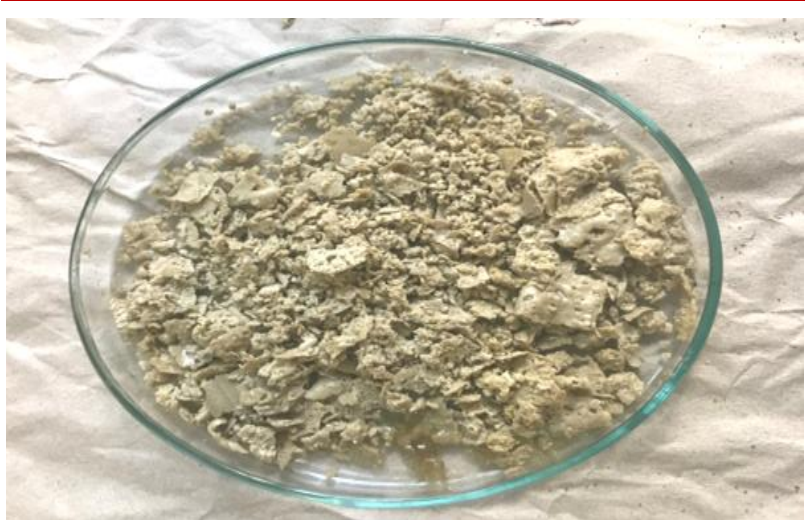

Suberites carnosus (Johnston, 1842)

\section{Ethical Approval}

Ethical approval is received by Maharashtra State Biodiversity Board, Nagpur for collection of sponges for research purpose. The voucher specimens of Sigmadocia fibulata and Suberites carnosus, was deposited at the repository centre at NIO Goa, India, as per the directions by Maharashtra State Biodiversity Board. The Voucher numbers of the said specimens are 1-NIO1006/18 (Sigmadocia fibulata) and 2NIO1007/18 (Suberites carnosus).

\section{Procurement of bacterial and fungal cultures}

The pure culture of bacteria E. coli, P. mirabilis, S.aureus, Vibrio cholera, Pseudomonas aeruginosa, E. faecalis, S. Typhi ,Candida albicans, and A. nigerwere collected from The Department Of
Microbiology, Patkar -Varde College, Goregaon (w), Mumbai and APX Laboratories, Thane, Maharashtra . The culture was stored in a refrigerator at $2-8{ }^{\circ} \mathrm{C}$. The nutrient media prepared by dissolving $5 \mathrm{~g}$ of peptone, $3 \mathrm{~g}$ beef extract, $8 \mathrm{~g}$ sodium chloride and $150 \mathrm{~g}$ agar in about $800 \mathrm{ml}$ of water and adjusting the $\mathrm{pH}$ of the solutions to 7.3 by drop wise addition of $1 \mathrm{~N}$ sodium hydroxide. The solution heated 2-3 minutes, cooled and diluted to 1 litter with distilled water. All the apparatus such as syringes, pipettes, conical flasks, Petridishes and the nutrient media sterilized in an autoclave before their use. A basic culture medium used for growing bacterial culture under laboratory condition as proposed by Pelczar [16]. The pure culture of bacteria E. coli, P. mirabilis, S.aureus, Vibrio cholera, Pseudomonas aeruginosa, E. faecalis, S. Typhi, Candida albicans, and A. niger were spread in sterile petridishes by streaking method. Total Ten petridishes were prepared. In all the petridishes, the crude extract of spong Sigmadocia fibulata (Schmidt) and Suberites carnosus (Johnston) was added on marked areas of all the petridishes by putting a whatman filter paper No. 40 (5 mm diameter) on the marked area of each of the petridish. $0.1 \mathrm{ml}$ of each of the crude extract placed on filter paper by injection vile. Control also maintained by adding methanol to the respective petridishes. Then petridishes kept for incubation for 24 hours at $37^{\circ} \mathrm{C}$.

\section{RESULTS AND DISCUSSION}

Table-1: Effect of crude extract of Sigmadocia fibulata (Schmidt) and Suberites carnosus (Johnston) showing zone of inhibition in Bacterial and Fungus Strains

\begin{tabular}{|l|l|l|l|l|}
\hline Sr. No & Name of bacteria & Presence/Absence & \multicolumn{2}{|l|}{ Zone of Inhibition(Diameter inmm) } \\
\cline { 4 - 5 } & & & Sigmadociafibulata & Suberites carnosus \\
\hline 1. & Streptococcuspneumoniae & Absent & - & - \\
\hline 2. & Coryne bacterium & Present & 2.5 & 4.5 \\
\hline 3. & Bacillus cereus & Absent & - & - \\
\hline 4. & E.coli & Present & 6.5 & 3.5 \\
\hline 5. & Pseudomonasaeruginosa & Absent & - & - \\
\hline 6. & Salmonellatyphi & Absent & - & - \\
\hline 7. & Proteusmirabilis & Present & 7.5 & 3.5 \\
\hline 9. & S. aureus & Absent & - & - \\
\hline 10. & Vibro cholera & Absent & - & - \\
\hline 11 & E. facalis & Absent & - & - \\
\hline 12. & A niger & Absent & - & - \\
\hline 13. & Candida albicans & Absent & - & - \\
\hline
\end{tabular}


Bhadekar N. S \& Zodape G. V., Saudi J Med Pharm Sci, Jan, 2021; 7(1): 32-38

Table-2: Effect of crude extract of Sigmadocia fibulata (Schmidt) and Suberites carnosus (Johnston) on mortality of Periplanata Americana

\begin{tabular}{|l|l|l|l|l|}
\hline Sr. No & $\begin{array}{l}\text { Concentration of } \\
\text { crude extract added } \\
\text { in } \boldsymbol{\mu l}\end{array}$ & $\begin{array}{l}\text { No. of Periplaneta } \\
\text { Americana } \\
\text { (cockroach) taken in } \\
\text { each jar }\end{array}$ & $\begin{array}{l}\text { Mean \% Mortality at } \\
\text { 24 hrs duration } \\
\text { Sigmadocia fibulata } \\
\text { (Schmidt) }\end{array}$ & $\begin{array}{l}\text { Mean \% Mortality at 24 } \\
\text { hrs duration Suberites } \\
\text { carnosus(Johnston) }\end{array}$ \\
\hline & 24 Hrs. \% Mortality & \multicolumn{2}{l|}{} \\
\hline 1 & 100 & 10 & 70 & 70 \\
\hline 2 & 200 & 10 & 90 & 80 \\
\hline 3 & 300 & 10 & 100 & 80 \\
\hline 4 & 400 & 10 & 100 & 80 \\
\hline 5 & 500 & 10 & 100 & 90 \\
\hline 6 & 600 & 10 & 100 & 90 \\
\hline 7 & 700 & 10 & 100 & 90 \\
\hline 8 & 800 & 10 & 100 & 90 \\
\hline 9 & 900 & 10 & 100 & 100 \\
\hline 10 & 1000 & 10 & 100 & 100 \\
\hline control & 00 & 10 & 00 & 00 \\
\hline
\end{tabular}

Each experiment were perform by five replicates

Table-3: Effect of crude extract of Sigmadocia fibulata (Schmidt) and Suberites carnosus (Johnston) on mortality of Rice weevil Sitopbilus oryzae (By Coating Method)

\begin{tabular}{|c|c|c|c|c|}
\hline Sr. No & $\begin{array}{l}\text { Concentration of } \\
\text { crude extract added } \\
\text { in } \mu \mathrm{l}\end{array}$ & $\begin{array}{l}\text { No. of Rice weevil } \\
\text { Sitopbilus oryzae } \\
\text { taken in each jar }\end{array}$ & $\begin{array}{l}\text { Mean \% Mortality at } 24 \\
\text { hrs duration } \\
\text { Sigmadocia fibulata } \\
\text { (Schmidt) }\end{array}$ & $\begin{array}{l}\text { Mean \% Mortality at } 24 \\
\text { hrs duration Suberites } \\
\text { carnosus(Johnston) }\end{array}$ \\
\hline & \multicolumn{3}{|l|}{24 Hrs. \% Mortality } & \\
\hline 1 & 100 & 10 & 40 & 30 \\
\hline 2 & 200 & 10 & 60 & 50 \\
\hline 3 & 300 & 10 & 50 & 40 \\
\hline 4 & 400 & 10 & 80 & 70 \\
\hline 5 & 500 & 10 & 80 & 80 \\
\hline 6 & 600 & 10 & 70 & 60 \\
\hline 7 & 700 & 10 & 90 & 90 \\
\hline 8 & 800 & 10 & 100 & 90 \\
\hline 9 & 900 & 10 & 100 & 100 \\
\hline 10 & 1000 & 10 & 100 & 100 \\
\hline control & 00 & 10 & 00 & 00 \\
\hline
\end{tabular}

Each experiment were perform by five replicates

Table-4: Effect of crude extract of Sigmadocia fibulata (Schmidt) and Suberites carnosus (Johnston) on mortality of Rice weevil Sitopbilus oryzae (By sprinkling Method)

\begin{tabular}{|c|c|c|c|c|}
\hline Sr. No & $\begin{array}{l}\text { Concentration of } \\
\text { crude extract added in } \\
\mu \mathrm{l}\end{array}$ & $\begin{array}{l}\text { No. of Rice weevil } \\
\text { Sitopbilus oryzae } \\
\text { taken in each jar }\end{array}$ & $\begin{array}{l}\text { Mean \% Mortality at } 24 \\
\text { hrs duration Sigmadocia } \\
\text { fibulata (Schmidt) }\end{array}$ & $\begin{array}{l}\text { Mean \% Mortality at } 24 \\
\text { hrs duration Suberites } \\
\text { carnosus(Johnston) }\end{array}$ \\
\hline & \multicolumn{3}{|l|}{24 Hrs. \% Mortality } & \\
\hline 1 & 100 & 10 & 50 & 40 \\
\hline 2 & 200 & 10 & 50 & 40 \\
\hline 3 & 300 & 10 & 60 & 50 \\
\hline 4 & 400 & 10 & 70 & 70 \\
\hline 5 & 500 & 10 & 80 & 50 \\
\hline 6 & 600 & 10 & 60 & 60 \\
\hline 7 & 700 & 10 & 80 & 80 \\
\hline 8 & 800 & 10 & 100 & 90 \\
\hline 9 & 900 & 10 & 100 & 100 \\
\hline 10 & 1000 & 10 & 100 & 100 \\
\hline control & 00 & 10 & 00 & 00 \\
\hline
\end{tabular}

Each experiment were perform by five replicates 


\section{DiscuSSION}

Nowadays people are more preferable use natural origin remedies than the synthetic drugs for curing illness because of their less side effects. Sponges are the amazing animals that develop strong immune system which resembles to that of other invertebrates.

Table-1 showing the effect of crude extract of Sigmadocia fibulata (Schmidt) and Suberites carnosus (Johnston) showing zone of inhibition in bacterial and fungus Strains.

In the present study Table-1 showing the effect of crude extract of Sigmadocia fibulata (Schmidt) and Suberites carnosus (Johnston) showing zone of inhibition in bacterial and fungus Strains. showing the effect of crude extract of Sigmadocia fibulata (Schmidt) and Suberites carnosus (Johnston) showing zone of inhibition in bacterial and fungus Strains. In our study we found that the crude extract of sponge Sigmadocia fibulata (Schmidt) and Suberites carnosus (Johnston) showed zones of inhibition as Coryne bacterium, $2.5 \mathrm{~mm}$ and $4.5 \mathrm{~mm}$, E.coli, $6.5 \mathrm{~mm}$ and $3.5 \mathrm{~mm}$, Proteusmirabilis, $7.5 \mathrm{~mm}$ and $3.5 \mathrm{~mm}$ in sponge Sigmadocia fibulata (Schmidt) and Suberites carnosus (Johnston) respectively. Whereas in case of Streptococcus pneumoniae, Bacillus cereus, Pseudomonas aeruginosa, Salmonella typhi, S. aureus, Vibro cholera, E. facalis, no bioactivity noted in respect of zone of inhibition. In case of fungal strains A. niger and Candida albicans no activity was noted against fungus when tested with crude extract of Sigmadocia fibulata (Schmidt) and Suberites carnosus (Johnston).We found the crude extract of sponge Sigmadocia fibulata (Schmidt) and Suberites carnosus (Johnston), more potent bioactivity was noted against Coryne bacterium, E.coli,Proteus mirabilis. It was evident from our study that, the crude extract of sponge Sigmadocia fibulata (Schmidt) and Suberites carnosus (Johnston), showed antibacterial activity. Our results were found contradictory to the studies carried out by Perveen et al., 2002 [17] stated that, the gram positive bacteria showing more activity than the gram negative bacteria. In another study, Beesoo et al., 2017 [18]; Gopi et al., 2012 [19]; Ines et al., 2007 [20] gives an evidence of the marine bacteria stating that marine gram positive bacteria has more sensitivity than gram negative bacteria. According to them gram negative bacteria are more resistant to sponge extract. The antimicrobial metabolic defense in sponges is well established [21, 22]. This could be because of natural marine environment Gupta et al., 2012 [23]; Mora et al., 2008 [24]; Nazemi et al., 2014 [25]. Many bioactive metabolites and compounds isolated from sponges displayed potential bioactivity such as antimicrobial, anti-inflammatory and cytotoxic activities [26, 27].
Table-2 Showing the effect of crude extract of Sigmadocia fibulata (Schmidt) and Suberites carnosus(Johnston)on mortality of Periplanata americana.

In control group $100 \%$ survival of the cockroach Periplaneta americana and Rice weevil Sitopbilus oryzae recorded after 24 hours. The experiments were conducted to find the effect of crude extract of Sigmadocia fibulata (Schmidt) and Suberites carnosus (Johnston) on cockroach Periplaneta americana. Data represented in Table-2. Show the mortality of cockroach Periplaneta americana after exposure to Sigmadocia fibulata (Schmidt) and Suberites carnosus (Johnston). It was found that, mortality ofcockroach Periplaneta americana was noted $100 \%$ after $24 \mathrm{hrs}$ exposure in the crude extract of Sigmadocia fibulata (Schmidt) was recorded at $300 \mu \mathrm{l}$ concentration and Suberites carnosus (Johnston) recorded at $900 \mu \mathrm{l}$ concentration. Cockroaches showed cleaning behavior at the initial stages of poisoning by rubbing their bodies with their legs or sides of the cages. Marentric movements of the mouth parts were also observed and at the later stages of poisoning tremors, incoordination and convulsion leading to paralysis were noted. Cockroaches in moribid condition were found to be dead after $24 \mathrm{hrs}$.

Table 3 and 4 Showing the Effect of crude extract of Sigmadocia fibulata (Schmidt) and Suberites carnosus (Johnston) on mortality of Rice weevil Sitopbilus oryzae (By Coating Method and by sprinkling Method).

Two kinds of experiments were conducted to find the effect of crude extract ofmarine sponges Sigmadocia fibulata (Schmidt) and Suberites carnosus (Johnston) on rice weevils Sitopbilus oryzae. Data represented in Table $3 \& 4$ show the mortality of rice weevils Sitopbilus oryzae after 24 hours of exposure to crude extract of Sigmadocia fibulata and Suberites carnosus. It was evident that bioactive compounds present in the crude extract shows bioactivity by inducing $100 \%$ mortality of the rice weevils after 24 hours exposure.

By coating method it was found that, mean mortality of rice weevils was noted $100 \%$ in Sigmadocia fibulata (Schmidt) $700 \mu 1$ and Suberites carnosus at 800 $\mu$ lconcentration. From the above data it was evident that Sigmadocia fibulata and Suberites carnosus contains bioactive compounds.

By sprinkling method the effect of crude extract of Sigmadocia fibulata and Suberites carnosus on mortality of rice weevils Sitopbilus oryzae. Data represented in Table-3, show the mean mortality of rice weevils Sitopbilus oryzae after 24 hours of exposure to 
crude extract of Sigmadocia fibulata noted $100 \%$ mortality in $800 \mu \mathrm{l}$ and in Suberites carnosus at $900 \mu 1$ concentration. In the initial stage of the experiment on Sitopbilus oryzae, after 2 hrs of exposure, schooling behavior was noted, and after 2 hrs the weevils were dispersed there after towards the corners of the petridishes, and after 6 hour the locomotary movement of the weevils was restricted and these weevils could not be moved afterwards. From the above data it was evident that the Sigmadocia fibulata and Suberites carnosus contains bioactive compounds. The pesticidal activity of the marine sponges Sigmadocia fibulata (Schmidt) and Suberites carnosus (Johnston) on mortality are being reported for the first time against cockroach Periplanata american and weevil Sitopbilus oryzae.

\section{CONCLUSION}

More potent bioactivity was noted against $\mathrm{P}$. mirabilis than E. coli. It was evident from our study that, the crude extract of sponge Sigmadocia fibulata (Schmidt) and Suberites carnosus (Johnston), showed effect on gram negative bacteria. Thus it concludes that sponge Sigmadocia fibulata (Schmidt) and Suberites carnosus (Johnston) have antibacterial and pesticidal activity. This finding is significant because multi-drug resistant strains of the organism are on the increase in both hospital and community environments against orthodox antibiotics and its control is very difficult by therapeutic means. Therefore it is necessary to screen the crude extract of sponge for its structural elucidation to find the new drugs for pharmaceutical industry.

\section{ACKNOWLEDGEMENT}

Authors would like to thank to, Dr. P. A. Thomas, Principal Scientist, Central Marine Fisheries Research Institute (CMFRI), Thiruvananthapuram, Kerala for identification of sponge species.

Conflict of Interest: There is no conflict of interest.

\section{REFERENCES}

1. Bergquist, P. R. (1978). Sponges, California: University of California Press. 268.

2. Hooper, J. N. A., \& Van Soest, R. W. M. (2002). Systema Porifera: a guide to the classification of sponges. New York: Plenum Publishers. 1:721723.

3. Sepcic, K., Batista, U., Vacelet, J., Macek, P., \& Turk, T. (1997). Biological activities of aqueous extracts from marine sponges and cytotoxic effects of 3-alkylpyridinium polymers from Reniera sarai. Comp Biochem Physiol. 117(1):4753.

4. Abas, H. H., Zulfigar, Y., \& Chan, K. L. (1999). Cytotoxicity and drug metabolism screening of several marine sponges from Pulau Pasir, Kedah and Pulau Aur, Johor. Asean Review of
Biodiversity and Environmental Conservation (ARBEC).

5. Thomas, P. A. Porifera. In: Alfred, J. R. B., Das, A. K., \& Sanyal, A. K., editors. (1998). Faunal diversity in India. Calcutta: ENVIS Central Zoological Survey of India. 28-36.

6. Newbold, R. W., Jensen, P. R., Fenical, W., \& Pawlik, J. R. (1999). Antimicrobial activity of Caribbean sponge extracts. Aquatic microbial ecology, 19(3), 279-284.

7. McConnell, O. J., Longley, R. E., \& Koehn, F. E. (1994). The discovery of marine natural products with therapeutic potential. Biotechnology (Reading, Mass.), 26, 109-174.

8. Rawat, D. S., Joshi, M. C., Joshi, P., \& Atheaya, H. (2006). Marine Peptides and Related Compounds in Clinical Trialt. Anti-Cancer Agents in Medicinal Chemistry (Formerly Current Medicinal Chemistry-Anti-Cancer Agents), 6(1), 33-40.

9. G Ravelo, A., Estévez-Braun, A., ChávezOrellana, H., Pérez-Sacau, E., \& Mesa-Siverio, D. (2004). Recent studies on natural products as anticancer agents. Current Topics in Medicinal Chemistry, 4(2), 241-265.

10. Newman, D. J., Cragg, G. M., \& Snader, K. M. (2003). Natural products as sources of new drugs over the period 1981- 2002. Journal of natural products, 66(7), 1022-1037.

11. Gullo, V. P., McAlpine, J., Lam, K. S., Baker, D., \& Petersen, F. (2006). Drug discovery from natural products. Journal of Industrial Microbiology and Biotechnology, 33(7), 523-531.

12. Tilvi, S., \& Naik, C. G. (2007). Tandem mass spectrometry of kahalalides: Identification of two new cyclic Depsipeptides, Kahalalide $\mathrm{R}$ and $\mathrm{S}$ from Elysia grandifolia. J Mass Spectrom. 42(1):70-80.

13. Vankateshwaran. (1997). Microchemolytic assay P-41-42 in Laboratory manual on advanced Techniques in marine Biotoxinology (Venka, K. \& Pani Prasad, K. Ed) CAS in Fishery science. CIFE Mumbai India: 76.

14. Zodape, G. V., Kulkarni, B. G., \& Argekar, A. P. (2008). Biopotential activity of the extract isolated from intertidal crab Leptodius exaratus Mumbai Nariman point coast". Pollution Research. 28(3):463-466.

15. Braekman, J. C., Daloze, D., Stoller, C., \& Van Soest, R. W. (1992). Chemotaxonomy of Agelas (Porifera: Demospongiae). Biochemical systematics and ecology, 20(5), 417-431.

16. Pelczar, M. J. (1993). Text book of microbiology. 5th edition, Tata McWell Hill publication.

17. Perveen, Z., Al-Lihaibi, S. S., Al-Sofyani, A. B. D. U. L. M. O. H. S. I. N., Niaz, G. R., \& Kornprobst, J. (2002). Preliminary investigations of antimicrobial screening of crude extracts of 
sponges and gorgonians species from Saudi Red Sea Coast. Pak. J. Pharmacol, 19(7).

18. Beesoo, R., Bhagooli, R., Neergheen-Bhujun, V. S., Li, W. W., Kagansky, A., \& Bahorun, T. (2017). Antibacterial and antibiotic potentiating activities of tropical marine sponge extracts. Comparative Biochemistry and Physiology Part C: Toxicology \& Pharmacology, 196, 81-90.

19. Gopi, M., Kumaran, S., Kumar, T. T. A., Deivasigamani, B., Alagappan, K., \& Prasad, S. G. (2012). Antibacterial potential of sponge endosymbiont marine Enterobacter sp at Kavaratti Island, Lakshadweep archipelago. Asian Pacific journal of tropical medicine, 5(2), 142-146.

20. Ines, T., Amina, B., Khaled, S., \& Kamel, G. (2007). Screening of antimicrobial activity of marine sponge extracts collected from Tunisian coast. In Proceedings of the Western Pharmacology Society. 50:152-155.

21. Gochfeld, D. J., Easson, C. G., Freeman, C. J., Thacker, R. W., \& Olson, J. B. (2012). Disease and nutrient enrichment as potential stressors on the Caribbean sponge Aplysina cauliformis and its bacterial symbionts. Marine Ecology Progress Series, 456, 101-111.
22. Rohde, R. A., \& Muller, R. A. (2015). Air pollution in China: mapping of concentrations and sources. PloS one, 10(8), e0135749.

23. Gupta, P., Sharma, U., Schulz, T. C., McLean, A. B., Robins, A. J., \& West, L. M. (2012). Bicyclic C21 terpenoids from the marine sponge Clathria compressa. Journal of natural products, 75(6), 1223-1227.

24. Mora, J. A., Newmark, F., Santos-Acevedo, M., \& Sánchez, J. (2008). Evaluation of marine sponge extracts as new sources of antimicrobial substances. Revista española de quimioterapia: Publicacion oficial de la Sociedad Española de Quimioterapia, 21(3), 174-179.

25. Nazemi, M., Alidoust Salimi, M., Alidoust Salimi, P., Motallebi, A., Tamadoni Jahromi, S., \& Ahmadzadeh, O. (2014). Antifungal and antimicrobial screening of crude extracts of sponges and gorgonians species from Saudi Red Sea Coast. Pak J Pharmacol. 19:7.

26. Agrawal, S., Adholeya, A., \& Deshmukh, S. K. (2016). The pharmacological potential of nonribosomal peptides from marine sponge and tunicates. Frontiers in pharmacology, 7, 333.

27. Malve, H. (2016). Exploring the ocean for new drug developments: Marine Pharmacology. J Pharma Bioallied Sci. 8:83-91. 